\title{
Pengaruh Perputaran Kas, Persediaan, Piutang, Modal Kerja Terhadap Profitabilitas Perusahaan
}

\author{
Siti Dini, Silvia Silalahi, Elverida Marpaung, Dewi. S. Sihombing, dan \\ Lestari Rajagukguk \\ Fakultas Ekonomi Universitas Prima Indonesia \\ Email: silviasilalahi1996@gmail.com
}

\begin{abstract}
Abstrak: Tujuan penelitian ini adalah untuk mengetahui pengaruh Perputaran Kas, Persediaan, Piutang, dan Modal Kerja terhadap Profitabilitas Perusahaan (BEI Tahun 20152017). Metode penelitian yang digunakan adalah pendekatan kuantitatif, jenis penelitian deskriptif dan sifatnya kausal kumulatif. Populasi penelitian sebanyak 50 perusahaan dan sampel sebanyak 14 perusahaan dengan teknik purposive sampling. Teknik pengumpulan data dengan cara dokumentasi dan sumber dari laporan keuangan BEI. Penelitian ini menggunakan uji regresi linier berganda sebelum dilakukan pengujian hipotesis data dan diuji menggunakan uj asumsi klasik. Hasil analisis koefisien determinasi diperoleh nilai adjust R Square sebesar 0,152 yang berarti variansi variabel Profitabilitas yang dapat dijelaskan oleh variabel Perputaran Kas, Persediaan, Piutang, dan Modal Kerja adalah sebesar $15,2 \%$ dan sisanya $84,8 \%$ dijelaskan oleh variabel lain. Penelitian ini menunujukkan bahwa secara simultan Perputaran, Persediaan, Piutang, dan Modal Kerja berpengaruh positif dan signifikan terhadap Profitabilitas. Secara parsial Perputaran Kas tidak berpengaruh terhadap Profitabilitas, Perputaran Persediaan berpengaruh negatif dan tidak signifikan terhadap Profitabilitas, Perputaran Piutang tidak berpengaruh terhadap Profitabilitas, Perputaran Modal Kerja berpengaruh positif signifikan terhadap Profitabilitas.
\end{abstract}

Kata kunci: Perputaran Kas, Perputaran Persediaan, Perputaran Piutang, dan Perputaran Modal Kerja terhadap Profitabilitas.

Abstract: The purpose of this study is to determine the effect of Cash Turnover, Inventory Turnover, Receivable Turnover, and Working Capital Turnover on Profitability in Consumers Manufacturing Industry Manufacturing Companies Listed on the Indonesia Stock Exchange in 2015-2017. The research method used quantitative approach, the type of descriptive research and its cumulative causal nature. The research population was 50 companies and the sample was 14 companies with a purposive sampling technique. Data collection techniques by means of documentation and sources of IDX financial statements. This study uses multiple linear regression test before testing the data hypothesis and tested using the classic assumption test. The results of the analysis of the coefficient of determination obtained $R$ Square value of 0.152, which means the variance of the profitability variable that can be explained by the variables Cash Turnover, Inventory Turnover, Receivable Turnover, and Working Capital Turnover is $15.2 \%$ and the remaining $84.8 \%$ is explained by other variables. This research shows that simultaneous cash turnover, inventory turnover, accounts receivable turnover, and working capital turnover have a positive and significant effect on profitability. Partially Cash Turnover has no effect on Profitability, Inventory Turnover has a negative andno significant effect 
on Profitability, Accounts Receivable Turnover has no effect on Profitability and Working Capital Turnoverpositive and significant effect on Profitability.

Keywords: Cash Turnover, Inventory Turnover, Receivables Turnover, and Working Capital Turnover on Profitability.

\section{LATAR BELAKANG}

Perkembangan perekonomian di Indonesia menyebabkan banyak munculnya organisasi bisnis salah satunya organisasi yang bergerak di bidang Sektor Industri Barang Konsumsi (Sarjito, 2017). Tujuan utama sebuah perusahaan mendirikan usaha bisnisnya adalah untuk memperoleh laba. Meningkatnya laba menjadi gambaran baik atau tidaknya kinerja sebuah perusahaan. Kinerja perusahaan yang baik dapat dilihat apabila perusahaan mampu memenuhi kebutuhan masyarakat melalui ketersediaan barang produksi. Namun pada perusahaan sektor industri barang konsumsi yang terdaftar di BEI beberapa tahun berjalan mengalami penurunan produktivitas. Hal ini dilihat dari laba sebagian perusahaan mengalami penurunan tahun 2015-2017.

Kinerja suatu perusahaan dapat dianalisis menggunakan rasio keuangan salah satunya rasio Profitabilitas. Profitabilitas berhubungan dengan kemampuan perusahaan memperoleh laba diukur dengan membandingkan laba bersih dengan total aktiva. Profitabilitas memiliki peran penting disuatu perusahaan dalam memperoleh laba untuk mendukung kegiatan operasionalnya (Ambarawati et al., 2016).

Kas berhubungan dengan investasi jangka pendek yang dimiliki perusahaan. Manager keuangan perusahaan dituntut harus merencanakan dengan baik jumlah kas yang tepat sesuai dengan kebutuhan perusahaan, karena jika perusahaan kelebihan kas menyebabkan dana menganggur sehingga menyebabkan perusahaan mengalami rugi. Sedangkan apabila terjadi kekurangan kas akan menghambat kegiatan operasional perusahaan. Perputaran kas periode berputarnya kas mulai dari saat kas diinvestasikan dalam modal kerja. Semakin tinggi perputaran kas akan semakin baik, karena menunjukkan semakin efisiensi penggunaan kasnya dan keuntungan yang di peroleh semakin besar (Arry dan Vera, 2019).

Persediaan sebagai aktiva lancar perusahaan nilainya cukup besar sehingga persediaan memiliki peran penting bagi perusahaan. Jumlah persediaan dalam perusahaan selalu berubah karena adanya pengurangan untuk proses produksi yang akan di jual pada konsumen. Adanya persediaan manajemen yang baik dalam perusahaan sehingga perusahaan secepatnya mengubah dana yang tersimpan dalam bentuk persediaan menjadi kas melalui penjualan untuk menghasilkan laba perusahaan. Perputaran persediaan mengukur ketepatan rata-rata persediaan yang keluar masuk perusahaan. Perputaran persediaan menyatakan berapa kali rata-rata persediaan barang jadi berputar atau terjual dalam satu periode tertentu (Christiana et al,, 2017)

Ketatnya persaingan dunia usaha menjadikan penjualan kredit menjadi upaya yang dilakukan untuk mempertahankan pelanggan sehingga menimbulkan piutang. Perusahaan perlu mengetahui seberapa besar tingkat piutang karena tingkat perputaran piutang sangat berpengaruh terhadap kelangsungan hidup perusahaan berkaitan dengan perolehan laba dihasilkan. Semakin tinggi penjualan kredit maka semakin banyak jumlah piutang dan laba yang di peroleh semakin besar (Dini, 2018). 
Keefektifan dan efisiensi modal kerja memiliki makna yang sama terhadap prinsip keuangan dasar. Perusahaan harus memenuhi kebutuhan modal kerja karena kelebihan atau kekurangan modal kerja mempengaruhi profitabilitas. Modal kerja berperan dalam menopang operasi atau kegiatan perusahaan, karena tanpa modal kerja kegiatan operasional suatu perusahaan tidak dapat berjalan lancar.

\section{KAJIAN TEORI}

Teori Pengaruh Perputaran Kas terhadap Profitabilitas. Menurut (Narufika dan Khairunnisa, 2018) Perputaran Kas memiliki pengaruh signifikan terhadap Profitabilitas. Perputaran kas menunjukkan kemampuan kas dalam menghasilkan pendapatan. Semakin tinggi perputaran kas akan semakin baik, yang artinya penggunaan kas tersebut sudah efisien dan keuntungan yang diperoleh semakin besar.

Menurut (Suminar, 2015) Perputaran Kas berpengaruh positif dan signifikan terhadap Profitabilitas. Semakin besar kas yang ada pada perusahaan, berarti semakin tinggi tingkat liquiditas perusahaan. Ini berarti bahwa perusahaan dapat memenuhi segala kewajiban yang ada dan lebih cepat dalam menentukan kebijakan yang berhubungan dengan financial perusahaan.

Menurut (Deni, 2014) perputaran kas berpengaruh positif dan signifikan terhadap Profitabilitas. Semakin tinggi perputaran kasnya maka keuntungan yang diperoleh akan semakin besar. Kas dapat digunakan untuk kepentingan lain seperti kas digunakan untuk menutupi kerugian yang disebabkan oleh adanya piutang tak tertagih, kas digunakan untuk pemeliharaan persediaan yang menumpuk digudang sehingga perputaran kas berpotensi besar dalam menentukan kenaikan laba perusahaan.

Perputaran kas menggambarkan seberapa besar kemampuan perusahaan dalam menghasilkan laba. Semakin tinggi tingkat perputaran kas berarti perusahaan efektif dalam mengelola aset perusahaan dan laba yang dihasilkan perusahaan semakin meningkat (Nurri et al., 2017).

Teori Pengaruh Perputaran Persediaan Terhadap Profitabilitas. Menurut (Narufika dan Khairunnisa, 2018) perputaran persediaan berpengaruh signifikan terhadap profitabilitas. Perusahaan mampu mengelola persediaan yang dimiliki menjadikan perputaran persediaan perusahaan tersebut dari tahun ke tahun mengalami peningkatan. Tingginya tingkat perputaran persediaan tergantung pada sifat barang, seperti resiko rusaknya barang yang akan menyebabkan menurunnya harga jual barang (Fahmi, 2018).

Menurut (Budiansyah et al., 2015) pengaruh rasio perputaran persediaan terhadap profitabilitas memiliki pengaruh positif dan signifikan. apabila tingkat perputaran persediaan semakin tinggi, maka semakin rendah tingkat resiko yang akan terjadi dan jumlah persediaan tidak terlalu besar. Resiko yang dimaksud seperti dalam penurunan harga, biaya pemeliharan, biaya penyimpanan, dan perubahan selera konsumen.

Menurut (Deni, 2014) perputaran persediaan memberikan pengaruh signifikan terhadap profitabilitas. Semakin lama periode perputaran persediaan, maka semakin banyak biaya yang harus dikeluarkan oleh perusahaan untuk menjaga agar persediaan digudang tetap baik. Oleh karena itu diperlukan penghematan ongkos penyimpanan dan pemeliharaan agar keuntungan yang diperoleh semakin besar . 
Persediaan dibutuhkan agar perusahaan dapat memenuhi kebutuhan konsumen. Semakin tinggi tingkat perputaran persediaan akan semakin baik. Tingginya tingkat perputaran persediaan menunjukkan keefektifan perusahaan dalam mengelola persediaan yang memungkinkan meningkatnya laba perusahaan.

Teori Pengaruh Perputaran Piutang Terhadap Profitabilitas. Menurut (Kadek et al., 2016) perputaran piutang memberikan pengaruh positif dan signifikan terhadap profitabilitas. Piutang berperan dalam upaya untuk meningkatkan profitabilitas dimana semakin tinggi perputaran piutang suatu perusahaan, semakin baik pengelolaan piutangnya menandakan pengelolaan laba perusahaan baik. Keadaan perputaran piutang yang tinggi menunjukkan bahwa semakin efisien dan efektif perusahaan mengelola piutang. Hal ini berarti profitabilitas perusahaan dapat dipertahankan.

Menurut (Widiasmoro, 2017) perputaran piutang menunjukkan pengaruh yang signifikan terhadap profitabilitas. Perputaran piutang akan menunjukkan berapa kali piutang timbul sampai piutang tersebut dapat tertagih kembali kedalam kas perusahaan. Semakin lama jangka waktu perputaran piutang akan berpotensi pada naiknya laba perusahaan.

Menurut (Tiong, 2017) perputaran piutang memberikan pengaruh positif dan signifikan terhadap profitabilitas. Perputaran piutang yang tinggi dapat menyebabkan rasio lancar yang cukup rendah yang dapat diterima dari sudut pandang likuiditas dan dapat menyebabkan pengembalian atas aktiva yang lebih tinggi. Sehingga laba yang tinggi dapat dipertahankan.

Piutang yang dilakukan perusahaan menjadi peluang meningkatnya laba perusahaan dan menjadi kesempatan perusahaan dalam menarik serta mempertahankan pelanggan. Piutang berperan dalam meningkatkan profitabilitas perusahan. Tingginya tingkat perputaran piutang berpotensi terhadap naiknya laba perusahaan.

Teori Pengaruh Perputaran Modal Kerja Terhadap Profitabilitas. Menurut (Puspita dan Ulil, 2018) pengaruh perputaran modal kerja memiliki pengaruh positif terhadap profitabilitas dimana perputaran modal kerja yang tinggi akan mempengaruhi tingginya tingkat profitabilitas perusahaan.

Menurut (Arinda dan Wiwik, 2015)(Novita, 2015) perputaran modal kerja memiliki pengaruh yang signifikan terhadap profitabilitas. Semakin cepat tingkat perputaran modal kerja perusahaan maka semakin banyak penjualan yang berhasil didapatkan sehingga semakin besar keuntungan yang diperoleh dan profitabilitas perusahaan akan meningkat.

Menurut (Novi et al., 2015) (Indah, 2019) pengaruh perputaran modal kerja memiliki pengaruh positif dan signifikan terhadap profitabilitas. Tingkat perputaran modal kerja menunjukkan efektifitas penggunaan penggunaan modal kerja. Semakin cepat modal kerja berputar semakin besar keuntungan yang didapat.

Perputaran modal kerja yang tinggi menunjukkan tingginya tingkat profitabilitas perusahaan. Perusahaan dikatakan efektif dalam mengelola modal kerjanya apabila profitabilitasnya tinggi. Perputaran modal kerja yang tinggi cenderung menunjukkan laba perusahaan juga tinggi. 


\section{Kerangka Konseptual}

Gambar 1. Kerangka Konseptual

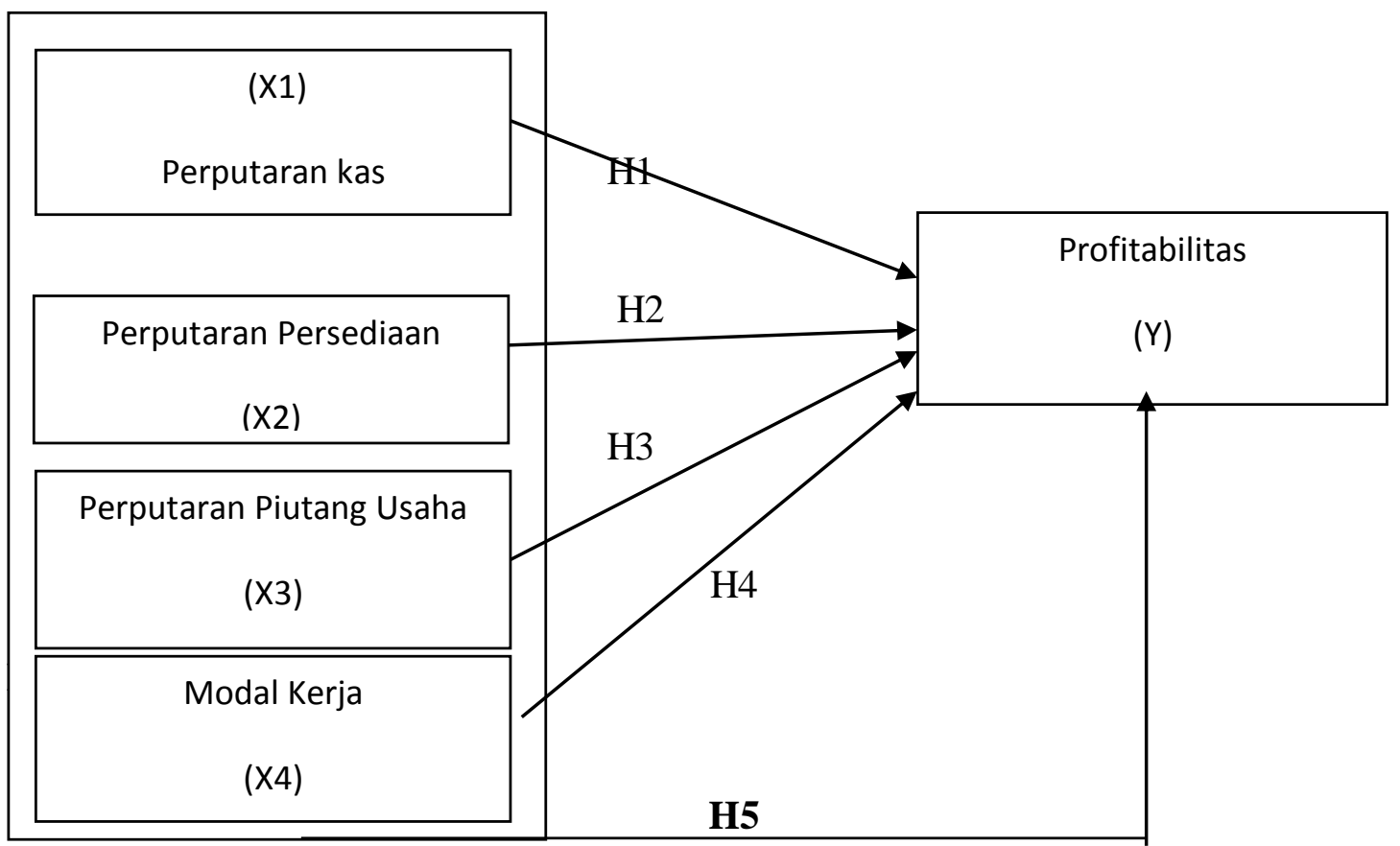

H1: Perputaran Kas berpengaruh secara parsial terhadap Profitabilitas pada perusahaan manufaktur sektor industri barang konsumsi di Bursa Efek Indonesia tahun 2015-2017.

H2 : Perputaran Persediaan berpengaruh secara parsial terhadap Profitabilitas pada perusahaan manufaktur Sektor Industri Barang Konsumsi di Bursa Efek Indonesia tahun 2015-2017.

H3: Perputaran Piutang berpengaruh secara parsial terhadap Probitabilitas pada perusahaan manufaktur Sektor Industri Barang Konsumsi di Bursa Efek Indonesia tahun 2015-2017.

H4 : Perputaran Modal Kerja berpengaruh secara parsial terhadap Profitabilitas pada perusahaan manufaktur Sektor Industri Barang Konsumsi di Bursa Efek Indonesia tahun 2015-2017.

H5: Perputaran Kas, Perputaran Persediaan, Perputaran Piutang, dan Perputaran Modal Kerja berpengaruh secara Simultan terhadap perusahaan manufaktur Sektor Industri Barang Konsumsi di Bursa Efek Indonesia tahun 2015-2017.

\section{METODOLOGI}

Pendekatan penelitian digunakan dalam penelitian ini adalah metode pendekatan kuantitatif. Menurut (Sugiyono, 2017), penelitian kuantitatif adalah metode penelitian dengan metode tradisional, positivistic, scientific dan metode discovery. Teknik pengambilan sampel pada umumnya dilakukan secara random, pengumpulan data menggunakan instrumen penelitian, analisis data bersifat kuantitatif/statistic dengan 
tujuan untuk menguji hipotesis yang telah ditetapkan. Jenis penelitian digunakan dalam penelitian ini adalah penelitian statistik deskriptif. Menurut (Sugiyono, 2017), penelitian statistik deskriptif adalah suatu rumusan masalah yang berkenaan dengan pertanyaan terhadap variabel mandiri, baik hanya satu variabel maupun lebih.. Penelitian statistik deskriptif berfokus pada penjelasan sistematis tentang fakta yang diperoleh saat penelitian dilakukan. Menurut (Sugiyono, 2017), penelitian statistik deskriptif adalah rumusan masalah yang berkenaan dengan pertanyaan terhadap variabel mandiri, baik hanya satu variabel maupun lebih.Sifat penelitian dalam penelitian ini adalah hubungan Kausal. Adapun kriteria pengambilan sampel dalam penelitian ini adalah (1) Perusahaan manufaktur sektor industri barang konsumsi yang terdaftar di BEI periode 2015-2017. (2) Perusahaan manufaktur sektor industri barang konsumsi yang tidak mempublikasikan lengkap laporan keuangan periode 2015-2017. (3) Perusahaan manufaktur sektor industri barang konsumsi yang mengalami kerugian periode 2015-2017.(4). Perusahaan manufaktur sektor industri barang kosumsi yang laba nya menurun setiap tahun periode 2015-2017. Total jumlah sampel yang digunakan dalam penelitian ini adalah 14 sampel selama 3 periode penelitian sehingga jumlahnya 42 sampel.

Defenisi Operasional Variabel Penelian. Perputaran Kas adalah rasio yang digunakan untuk mengukur tingkat kecukupan modal kerja perusahaan yang dibutuhkan untuk membayar tagihan dan membiayai penjualan. (Kasmir 2014).

Perputaran Kas $=\frac{\text { Penjualan }}{(\text { Rata }- \text { Rata Kas })}$

Perputaran Persediaan adalah rasio yang digunakan untuk mengukur berapa kali dana yang ditanam dalam persediaan ini berputar dalam satu periode. (Kasmir, 2014).

Perputaran Persediaan $=\frac{\text { Harga Pokok Penjualan }}{\text { Rata }- \text { Rata Persediaan }}$

Perputaran Piutang adalah rasio yang digunakan untuk mengukur seberapa lama penagihan piutang perusahaan selama satu periode tertentu. Atau berapa kali dana yang ditanam dalam persediaan ini berputar dalam satu periode tertentu. (Kasmir, 2014)

Perputaran Piutang $=\frac{\text { Penjualan }}{(\text { Rata }- \text { Rata Piutang })}$.

Perputaran Modal Kerja adalah rasio yang digunakan untuk mengukur keefektifan modal kerja (aset lancar) yang dimiliki perusahaan dalam menghasilkan penjualan. Atau rasio untuk mengukur keefektifan penggunaan modal kerja selama periode tertentu. (Hery, 2015)

Perputaran Modal Kerja $($ Fahmi 2016:110 $)=\frac{\text { Penjualan }}{\text { Rata }- \text { rata aset lancar }}$.........

Teknik pengumpulan data dalam penelitian ini adalah dengan cara Studi dokumentasi dan Kepustakaaan. Dokumen yang digunakan adalah laporan keuangan perusahaan manufaktur sektor Industri Barang Konsumsi yang terdaftar di Bursa Efek 
Indonesia periode 2015-2017. Kepustakaan yakni pengumpulan data pendukung berupa literature, penelitian terdahulu dan buku-buku rujukan untuk mendapatkan gambaran dari masalah yang akan diteliti.

\section{HASIL DAN PEMBAHASAN}

Data statistik secara keseluruhan dapat dilihat dari pengujian statistik deskriptif dengan menggunakan spss 25 (Ghozali, 2013). Tabel statistik deskriptif dapat dilihat jumlah maksimum, minimum, meandan std deviation untuk setiap variabel.

Tabel 1. Statistic deskriptif

\begin{tabular}{l|l|l|l|l|l}
\hline & $\mathbf{N}$ & Minimum & Maximum & Mean & Std. Deviation \\
\hline Perputarankas & 42 & 11.000 & 255629.000 & 32020.33333 & 46525.395228 \\
\hline Perputaranpersediaan & 42 & 1119.000 & 1724874.000 & 45737.80952 & 265424.508480 \\
\hline Perputaranpiutang & 42 & 3282.000 & 45392.000 & 9757.64286 & 9569.037974 \\
\hline Perputaranmodalkerja & 42 & 689.000 & 6064.000 & 2535.00000 & 1232.571158 \\
\hline ROA & 42 & .000 & 553.000 & 134.30952 & 128.890100 \\
\hline Valid N (listwise) & 42 & & & & \\
\hline
\end{tabular}

Perputaran Kas nilai minimumsebesar 11 kali pada PT Ultrajaya Milk Industry \&Trading Company Tbk tahun 2016. Maksimum 255.629 kaliterdapat pada PT. Pyridam Farma Tbk tahun 2017. Rata-rata sebesar 32.020,33kali. Nilai std Deviation 46.525,39kali.

Perputaran Persediaan nilai minimum sebesar 4kaliterdapat pada PT. Kimia Farma (Persero), Tbk tahun 2017.Nilai maksimum8.491kalipada PT Unilever Indonesia Tbk tahun 2016. Nilai rata-rata sebesar 4.585,80 kali. Nilai std Deviation 2.354,30 kali.

Perputaran Piutang nilai minimum3.282kali terdapat pada PT. Budi Starch \& Sweetener Tbk tahun 2015.Nilai maksimum 45.392kali terdapat pada PT. Gudang Garam Tbk dan Entitas Anak tahun 2015. Nilai rata-rata sebesar 9.757,64 kali. Nilai std Deviation 9.569,03 kali.

Perputaran Modal Kerja nilai minimum 689kali pada PT. Delta Djakarta Tbk (DLTA) tahun 2017.Nilai maksimum 6.064kali terdapat pada PT. Unilever Indonesia Tbk tahun 2016. Rata-rata sebesar2.535 kali. Nilai std Deviation 1.232,57 kali.

Profitabilitas dengan indikator ROA. Nilai minimum 0 \%terdapat pada PT. Ultrajaya Milk Industry \& Trading Company Tbk tahun 2016.Nilai maksimum 55\%terdapat pada PT.Multi Bintang Indonesia Tbk Dan Entitas Anak tahun 2017. Rata-rata sebesar $134,30 \%$. Nilai std Deviation $128,89 \%$. 


\section{Hasil Uji Asumsi Klasik}

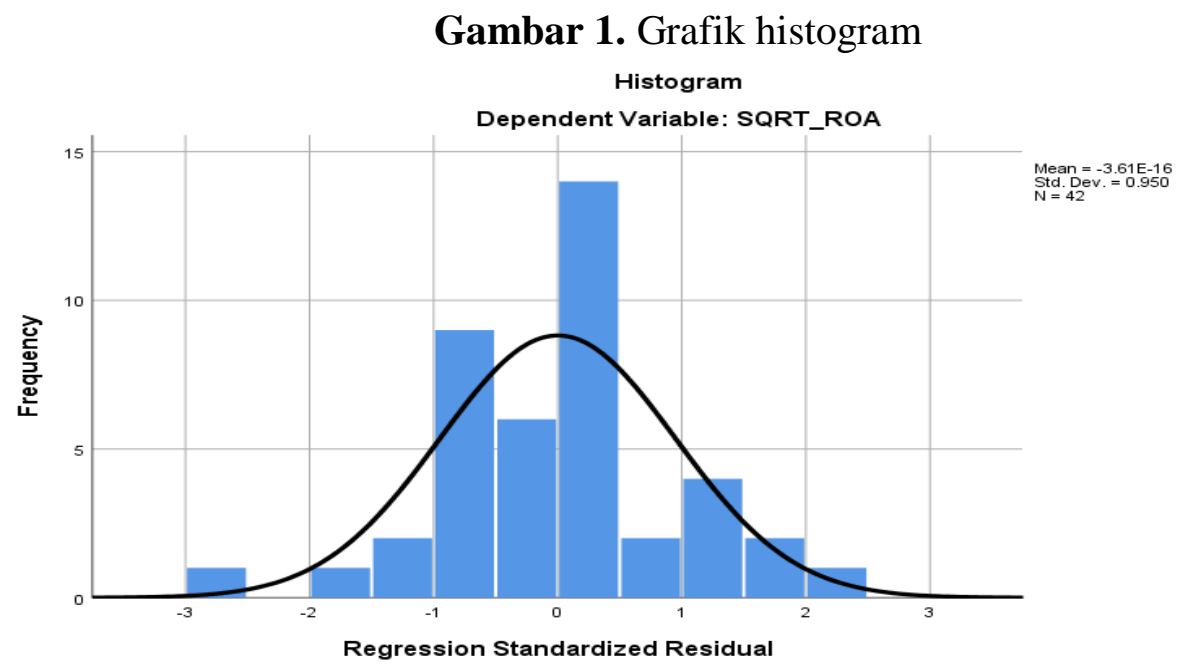

Grafik Histogram gambaran pola data yang baik, frequency pada gambar menunjukkan tampilan tinggi pada pola data.

Gambar 2. Uji Normalitas P-P Plot

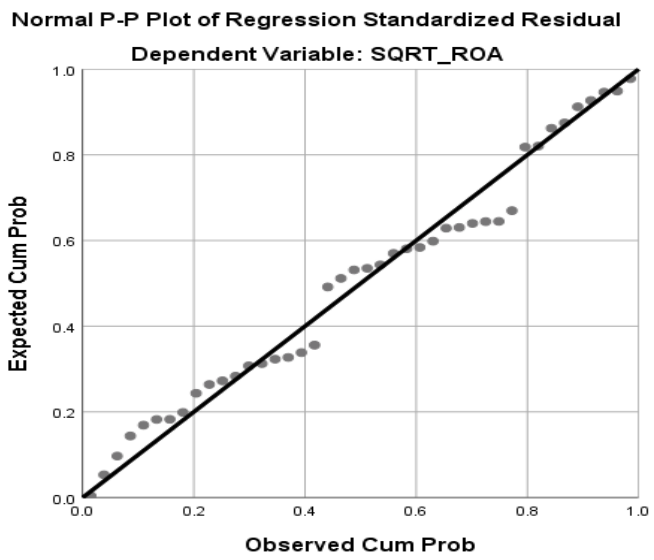

Grafik normal P-PPlot menunjukkan gambaran pola data yang baik, pada semua titik excepted cum prob dan observed cum prov data tersebar disekitar garis diagonal menunjukkan data berdistribusi dengan normal dan model regresi beramsumsi normal.

Tabel 2.Uji normalitas kolmogorov smirnov

\begin{tabular}{lll}
\hline \multicolumn{2}{l}{ One-Sample Kolmogorov-Smirnov Test } & \\
\hline $\mathbf{N}$ & & Sqrt_ROA \\
\hline Normal Parametersa,b & Mean & 42 \\
\hline & Std. Deviation & 10.3764 \\
\hline Most Extreme Differences & Absolute & .123 \\
\hline & Positive & .123 \\
\hline & Negative & -.083 \\
\hline Test Statistic & .123
\end{tabular}


Asymp. Sig. (2-tailed)

$$
.116 \mathrm{c}
$$

Tabel 2 nilai one sample kolmogorov-smirnov 0,116. Data berdistribusi normal, nilai signifikan sudah diatas 0,05 .

\section{Uji Multikolinearitas}

Tabel 3.Uji Multikolinearitas

Coefficients a

Model

1(Constant)

SQRT_perputarankas

SQRT_perputaranpersediaan

SQRT_perputaranpiutang

SQRT_perputaranmodalkerja

3.381

\section{Unstandardized Coefficients}

B

.954

$-.027$

$-.060$

.004
Std. Error

3.812

.009

.057

.022

.347
Tolerance

.566

.425

.861

.117

\section{Collinearity Statistics}

VIF

1.767

2.355

1.162

Uji Multikolinearitas bertujuan untuk mengetahui apakah dalam model regresi ditemukan adanya korelasi antar variabel independen. Apabila nilai VIF kurang dari 10 dan Tolerance lebih dari 0,1 maka dapat disimpulkan tidak terjadi multikolinearitas. Berdasarkan tabel Perputaran kas, Perputaran Persediaan, Perputaran Piutang, dan Perputaran Modal Kerja nilai tolerance lebih besar dari 0,10 dan nilai VIF sebesar lebih kecil dari 10 disimpulkan tidak terjadi multikolinearitas.

\section{Uji Autokorelasi}

Tabel 4. Uji Durbin-Watson

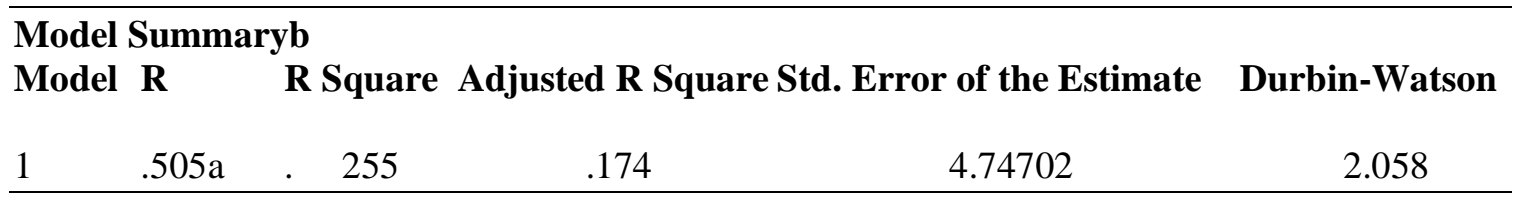

Uji Autokorelasi bertujuan menguji apakah dalam model regresi linier ada korelasi antara kesalahan pengganggu pada periode t-1 (periode sebelumnya). Cara mendeteksi terjadi atau tidaknya autokorelasi dalam penelitian adalah dengan menggunakan analisis uji Durbin Watson dimana nilai $\mathrm{dw}>\mathrm{du}$ dan $(4-\mathrm{dw})>\mathrm{dw}$. Tabel menunjukkan nilai DW adalah 2,058. Jumlah $\mathrm{K}=4$ dan $\mathrm{n}=42$ maka nilai dl 1,3064 dan du 1,7202. Nilai DW diperoleh lebih besar dari nilai du dan lebih kecil dari nilai 4-du $=4-1,7202=2,2798$ yaitu $1,7202<2,058<2,278$ artinya tidak terjadi autokorelasi. 


\section{Uji Heterokedastisitas}

Gambar 3. Uji Heteroskedastisitas

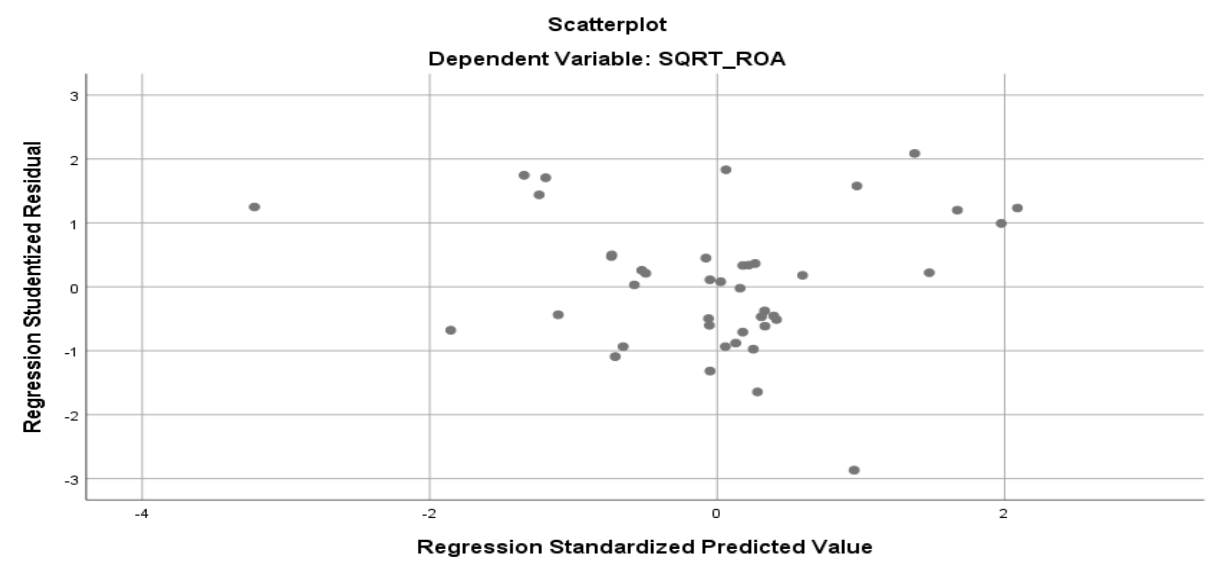

Gambar 3 menunjukkan sebaran pola titik-titik terpencar jauh dan menyebar secara acak sehingga tidak membentuk pola. Maka disimpulkan tidak terjadi Heteroskedastisitas.

Tabel 5. Uji Glejser

Coefficientsa

Model

Statistics

VIF

$1 \quad$ (Constant)

1.767

SQRT_perputarankas

2.355

1.162

3.381

SQRT_perputaranpiutang

\section{Unstandardized Coefficients}

Std. Error Sig

2.254

$$
\begin{aligned}
& .263 \\
& .006
\end{aligned}
$$

.034 .289

.013

.582

.069

.069

\section{Collinearity}

Tolerance

346
.566

$$
\text { SQRT_perputaranpersediaan }
$$

SQRT_perputaranmodalkerja

a. Dependent Variable: Absress2

Uji Glejser bertujuan mengetahui apakah dalam sebuah model regresi ini terjadi ketidaksamaan varian dari residual suatu pengamatan kepengamatan lain. Uji Glejser yang tidak terdapat gejala Heterokedastisitas apabila nilai signifikansi variabel diatas 0,05.Tabel menunjukkan Perputaran Kas, Perputaran Persediaan, Perputaran Piutang, dan Perputaran Modal Kerja nilai signifikan lebih besar dari 0,05 disimpulkan tidak terjadi heteroskedastisitas antar variabel independen dalam model regresi. 
Tabel 6. Analisis Regresi Linear Berganda

\begin{tabular}{|c|c|c|c|c|c|c|}
\hline \multirow{3}{*}{$\begin{array}{l}\text { Coefficientsa } \\
\text { Model } \\
\text { StatisticS }\end{array}$} & \multirow{2}{*}{\multicolumn{5}{|c|}{ Unstandardized Coefficients }} & \multirow[b]{2}{*}{ Collinearity } \\
\hline & & & & & & \\
\hline & B & \multicolumn{2}{|c|}{ Std. Error } & Beta & \multicolumn{2}{|c|}{ Tolerance } \\
\hline \multicolumn{7}{|l|}{ VIF } \\
\hline $1($ Constant $)$ & 95 & & 3.8 & & & \\
\hline SQRT_perputarankas & -.027 & .009 & -.54 & & .566 & 1.767 \\
\hline SQRT_perputaranpersediaan & -.060 & .057 & -.23 & & .425 & 2.355 \\
\hline SQRT_perputaranpiutang & .004 & .022 & .02 & & .861 & 1.162 \\
\hline SQRT_perputaranmodalkerja & .347 & .117 & .77 & & .296 & 3.381 \\
\hline
\end{tabular}

Model regresi linier berganda yang diperoleh maka dapat dirumuskan sebagai berikut: $\mathrm{Y}=0,954-0,027$ perputaran kas -0.060 perputaran persediaan $+0,004$ perputaran piutang $+0,347$ perputaran modal kerja:

(1) Nilai konstanta 0,954 artinya jika variabel Perputaran Kas, Perputaran Persediaan, Perputaran Piutang, dan Perputaran Modal Kerja dianggap 0, maka nilai perubahan laba sebesar 0,954. (2) Perputaran Kas memiliki koefisien regresi sebesar 0,027. Artinya setiap kenaikan perputaran kas senilai satu satuan, maka terjadi perubahan laba sebesar -0,027. (3) Perputaran Persediaan memiliki koefisien regresi sebesar -0,060. Artinya setiap kenaikan perputaran persediaan senilai satu satuan, maka terjadi perubahan laba sebesar -0,060. (4) Perputaran Piutang memiliki koefisien regresi sebesar 0,004. Artinya setiap kenaikan perputaran piutang senilai satu satuan, maka terjadi perubahan laba sebesar 0.004. (5) Perputaran Modal Kerja memiliki koefisien regresi sebesar 0,347. Artinya setiap kenaikan perputaran modal kerja senilai satu satuan, maka terjadi perubahan laba sebesar 0,347 .

\section{Koefisien Determinasi Hipotesis}

Tabel 7. Uji Koefisien Determinasi

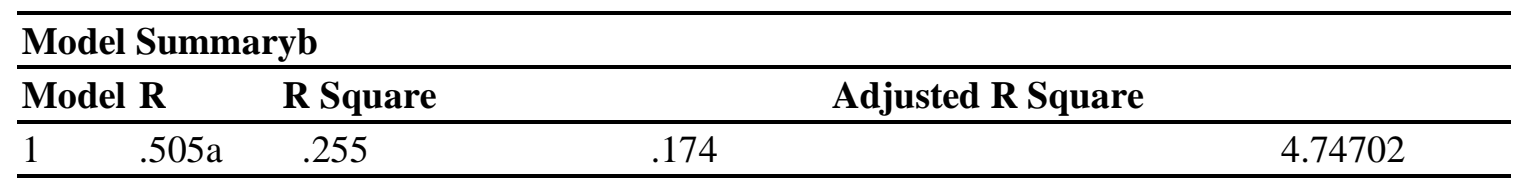

Koefisien determinasi adjusted $\mathrm{R}^{2}$ tujuannya mengukur seberapa jauh kemampuan maupun model dalam menerangkan variabel-variabel dependen. Tabel 7 nilai adjust $\mathrm{R}^{2}$ sebesar $0,174^{\text {a }}$ atau $17,4 \%$ berarti hubungan antar variabel $\mathrm{X}$ dan $\mathrm{Y}$ adalah kuat. Sedangkan 82,6\% dijelaskan pada variabel lain dari luar penelitian seperti Perputaran Aktiva Tetap, Perputaran Total Aktiva, Margin Laba Bersih. 


\section{Pengujian H Hipotesis Secara Simultan}

Tabel 8. Uji F

\begin{tabular}{llccccc}
$\begin{array}{l}\text { ANOVA } \\
\text { Model }\end{array}$ & Sum of Squares & Df & Mean Square & F & Sig. \\
1 & Regression & 285.146 & 4 & 71.287 & 3.163 & $.025^{\mathrm{b}}$ \\
\hline $\begin{array}{l}\text { Residual } \\
\text { Total }\end{array}$ & 833.766 & 37 & 22.534 & & \\
\hline
\end{tabular}

Uji $\mathrm{F}$ menunjukkan apakah semua variabel independen atau bebas yang dimasukkan dalam model mempunyai pengaruh secara bersama-sama terhadap variabel

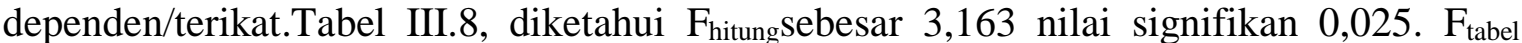
pada tingkat kepercayaan 0,95nilai signifikan 0,05 dimana $\mathrm{n}=42$ dan $\mathrm{k}=5$ dengan penjelasan $n-k-1=36$ adalah sebesar 2,63. Nilai $F_{h i t u n g} 3,163>F$ tabel 2,63 dan nilai signifikan $0,025<0,05$ menunjukkan bahwa variabel Perputaran Kas, Perputaran Persediaan, Perputaran Piutang, dan Perputaran Modal Kerja berpengaruh positif dan signifikan terhadap Profitabilitas pada Perusahaan Sektor Industri Barang Konsumsi di Bursa Efek Indonesia Periode 2015-2017.

\section{Pengujian Hipotesis Secara Parsial}

Tabel 9. Uji t

\begin{tabular}{|c|c|c|c|c|c|}
\hline \multicolumn{6}{|c|}{ Model } \\
\hline & & B & Beta & $\mathbf{t}$ & Sig \\
\hline $\begin{array}{l}1 \\
.804\end{array}$ & (Constant) & .954 & & .250 & \\
\hline \multirow{3}{*}{.006 } & SQRT_perputarankas & -.027 & & -.545 & -2.887 \\
\hline & SQRT_perputaranpersediaan & .060 & -.231 & -1.063 & .295 \\
\hline & SQRT_perputaranpiutang & & .004 & .027 & \\
\hline .862 & SQRT_perputaranmodalkerja & .347 & .772 & 2.960 & .005 \\
\hline
\end{tabular}

Hasil uji statistik secara parsial dijelaskan seperti dibawah ini:

Perputaran kas memiliki nilai $t_{\text {hitung }}$ sebesar -2,887 dengan nilai signifikan 0,006 sedangkan $\mathrm{t}_{\text {tabel }}$ yaitu $\mathrm{n}-\mathrm{k}-1=36$ adalah sebesar 2,02809 dengan nilai signifikan $<0,05$. Maka kesimpulannya $t_{\text {hitung }}<\mathrm{t}_{\text {tabel }}$ yaitu $-2,887<-2,02809$ dan nilai signifikan 0,006 < 0,05 maka $\mathrm{H}_{0}$ diterima dan $\mathrm{H}_{\mathrm{a}}$ ditolak. Artinya Perputaran Kas tidak berpengaruh terhadap Profitabilitas pada perusahaan Manufaktur Sektor Industri Barang Konsumsi periode 2015-2017.

Perputaran persediaan memiliki nilai thitung sebesar -1,063 dengan nilai signifikan 0,862 sedangkan tabel yaitu $n-k-1=36$ adalah sebesar 2,02809 dengan nilai signifikan > 0,295 . Maka kesimpulannya $t_{\text {hitung }}>t_{\text {tabel }}$ yaitu $-1,063>-2,02809$ dan nilai signifikan 0,295 > 0,05 maka $\mathrm{H}_{0}$ ditolak dan $\mathrm{H}_{\mathrm{a}}$ diterima. Artinya Perputaran Persediaan berpengaruh 
negatif dan tidak signifikan terhadap Profitabilitas pada perusahaan Manufaktur Sektor Industri Barang Konsumsi periode 2015-2017.

Perputaran Piutang memiliki nilai thitung sebesar 0,175 dengan nilai signifikan 0,729 sedangkan $\mathrm{t}_{\text {tabel }}$ yaitu $\mathrm{n}-\mathrm{k}-1=36$ adalah sebesar 2,02809 dengan nilai signifikan $>0,05$. Maka kesimpulannya $t_{\text {hitung }}<t_{\text {tabel }}$ yaitu $0,175<2,02809$ dan nilai signifikan 0,862 $>0,05$ maka $\mathrm{H}_{0}$ diterima dan $\mathrm{H}_{\mathrm{a}}$ diterima. Artinya Perputaran Piutang tidak berpengaruh terhadap Profitabilitas pada perusahaan Sektor Industri Barang Konsumsi periode 2015-2017.

Perputaran Modal Kerja memiliki nilai $t_{\text {hitung }}$ sebesar 2,960 dengan nilai signifikan 0,005 sedangkan $t_{\text {tabel }}$ yaitu $n-k-1=36$ adalah sebesar 2,02809 dengan nilai signifikan < 0,05 . Maka kesimpulannya $t_{\text {hitung }}>t_{\text {tabel }}$ yaitu 2,960 > 2,02809 dan nilai signifikan $0,005<$ 0,05 maka $\mathrm{H}_{0}$ ditolak dan $\mathrm{H}_{\mathrm{a}}$ diterima. Artinya Perputaran Modal Kerja berpengaruh positif dan signifikan terhadap Profitabilitas pada perusahaan Manufakur Sektor Industri Barang Konsumsi periode 2015-2017.

\section{DISKUSI}

Pengaruh Perputaran Kas Terhadap Profitabilitas (ROA). Berdasarkan hasil pengujian hipotesis secara parsial, Perputaran Kas tidak berpengaruh terhadap Profitabilitas pada perusahaan Manufaktur Sektor Industri Barang Konsumsi dalam Bursa Efek Indonesia periode 2015-2017 (Kezia et al., 2017); (Eka, 2014).

Perusahaan kurang efektif dalam mengelola penggunaan kas sehingga berpengaruh terhadap profitabilitas perusahaan. Adanya penggunaan kas pada fungsi lain seperti menutupi kerugian piutang tak tertagih dari pelanggan, menyebabkan pengelolaan kas kurang efektif. Perusahaan harus mengelola perputaran kas secara efektif dan efisien karena pengelolaan perputaran kas secara efektif dan efisien, berdampak pada profitabilitas perusahaan tinggi yang artinya kas semakin cepat masuk kembali pada perusahaan. Jadi perusahaan dapat membiayai kembali kegiatan operasional perusahaan serta memiliki peluang untuk investasi lebih besar. Selain itu perusahaan juga harus mampu meminimalkan penggunaan kas untuk kegiatan operasional perusahaan dengan memperhatikan efisiensi penggunaan kas (Matilda, 2017).

Pengaruh Perputaran Persediaan Terhadap Profitabilitas (ROA). Berdasarkan hasil pengujian hipotesis secara Parsial, Perputaran Persediaan berpengaruh negatif dan tidak signifikan terhadap Profitabilitas pada perusahaan Manufaktur Sektor Industri Barang Konsumsi dalam Bursa Efek Indonesia periode 2015-2017.

Hasil penelitian ini sejalan dengan hasil penelitian terdahulu (Budiansyah et al., 2015) dengan judul penelitian" Pengaruh Perputaran Kas, Perputaran Piutang, dan Perputaran Persediaan Terhadap Profitabilitas perusahaan Manufaktur Basic Industry and Chemicals selama periode 2012-2014"

Perusahaan dalam mengelola stock persediaan digudang yang akan dijual kepada konsumen sudah efektif. Permintaan konsumen terhadap barang yang diinginkan selalu tersedia oleh perusahaan. Namun Perusahaan kurang memperhatikan sifat barang yang cepat rusak sehingga terdapat pengaruh negatif persediaan terhadap Profitabilitas. Maka perusahaan perlu memperhatikan stock persediaan yang disimpan digudang karena apabila barang terlalu lama disimpan digudang menyebabkan barang rusak dan menurunkan harga jual barang. Perusahaan harus memperhatikan resiko rusaknya barang untuk menghindari 
terjadinya penurunan harga penjualan barang yang mengakibatkan berkurangnya laba yang diperoleh perusahaan.

Pengaruh Perputaran Piutang Terhadap Profitabilitas (ROA). Berdasarkan hasil pengujian hipotesis secara parsial, Perputaran Piutang tidak berpengaruh dan tidak signifikan terhadap Profitabilitas pada perusahaan Manufaktur Sektor Industri Barang Konsumsi dalam Bursa Efek Indonesia periode 2015-2017.

Hasil penelitian ini tidak sejalan dengan hasil penelitia (Agustia et al., 2016) dengan judul penelitian "Pengaruh Perputaran Kas, Perputaran Piutang, dan Perputaran Persediaan terhadap Profitabilitas pada Perusahaan Manufaktur di Bursa Efek Indonesia Tahun 2014" yang menyatakan bahwa perputaran piutang memiliki pengaruh yang positif dan signifikan terhadap profitabilitas (Ririn dan Rusnaeni, 2018) (Nurul, 2014).

Pengelolaan penjualan kurang efektif berpengaruh terhadap laba perusahaan. Dalam hal ini perusahaan meningkatkan jumlah penjualan kredit namun pada bagian penjualan kredit tertentu terdapat piutang tidak tertagih dari pelanggan sehingga menyebabkan penurunan laba perusahaan. Faktor lain yang menyebabkan kurang efektif dan efisiennya pengelolaan piutang yaitu perusahaan kurang memperhatikan pengelolaan piutang dengan melihat indikasi syarat pembayaran piutang. Jika syarat pembayaran piutang lemah maka berakibat pada naiknya jumlah piutang tetapi perputaran piutang akan semakin rendah dan jika syarat pembayaran piutang ketat maka akan menurunkan jumlah piutang dan menaikkan tingkat perputaran piutang. Syarat pembayaran piutang berpengaruh terhadap penjualan dan selanjutnya berimbas pada profitabilitas perusahaan. Untuk menghindari kemungkinan terjadinya piutang tidak tertagih dari pelanggan, maka perusahaan harus memperhatikan syarat pembayaran piutang yang diberikan kepada pelanggan.

Pengaruh Perputaran Modal Kerja Terhadap Profitabilitas (ROA). Berdasarkan hasil pengujian hipotesis secara parsial, Perputaran Modal Kerja berpengaruh positif dan signifikan terhadap Profitabilitas pada perusahaan Manufaktur Sektor Industri Barang Konsumsi dalam Bursa Efek Indonesia periode 2015-2017 (Satria dan Lestari, 2014) (Handayani, 2016) (Rany, 2017).

Perusahaan dalam mengelola modal kerja berupa aset lancar telah efektif dan efisien. Dalam hal ini peran modal kerja dalam menopang kegiatan operasional perusahaan telah terlaksana dengan baik. Pengelolaan modal kerja yang baik mendorong kenaikan laba perusahaan. Hasil tersebut menunjukkan bahwa semakin tinggi volume penjualan yang dihasilkan maka modal kerja berputar semakin cepat dengan keuntungan yang semakin tinggi. Besarnya keuntungan yang diperoleh perusahaan akan menaikkan tingkat profitabilitas perusahaan. Tingkat perputaran modal kerja menunjukkan efektifitas penggunaan modal kerja dalam perusahaan. Perusahaan diharapkan mampu mempertahankan tingkat perputaran modal kerja karena dengan tingginya tingkat perputaran modal kerja maka profitabilitas perusahaan dapat dipertahankan (Rofi, 2018). 


\section{KESIMPULAN}

Berdasarkan hasil penelitian yang dilakukan secara parsial, Perputaran Kas tidak berpengaruh terhadap Profitabilitas pada perusahaan Manufaktur Sektor Industri Barang Konsumsi dalam Bursa Efek Indonesia periode 2015-2017. Hasil penelitian yang dilakukan secara parsial, Perputaran Persediaan berpengaruh negatif dan tidak signifikan terhadap Profitabilitas pada perusahaan Manufaktur Sektor Industri Barang Konsumsi dalam Bursa Efek Indonesia periode 2015-2017.

Berdasarkan hasil secara parsial, Perputaran Piutang tidak berpengaruh terhadap Profitabilitas pada perusahaan Manufakur Sektor Industri Barang Konsumsi dalam Bursa Efek Indonesia periode 2015-2017.

Perputaran Modal Kerja berpengaruh positif dan signifikan terhadap Profitabilitas pada perusahaan Manufaktur Sektor Industri Barang Konsumsi dalam Bursa Efek Indonesia periode 2015-2017.

Disimpulkan bahwa Perputaran Kas, Perputaran Persediaan, Perputaran Piutang, dan Perputaran Modal Kerja berpengaruh positif dan signifikan terhadap Profitabilitas pada Perusahaan Manufaktur Sektor Industri Barang Konsumsi dalam Bursa Efek Indonesia periode 2015-2017.

Saran. Bagi pihak Investor Untuk terlebih dahulu menganalisa rasio keuangan terutama rasio keuangan berhubungan dengan Profitabilitas perusahaan karena itu menunjukkan kemampuan perusahaan efektif mengelola keuangan perusahaan dan berdampak pada kenaikan laba. Bagi pihak perusahaan diharapkan untuk dapat mengelola Kas, Persediaan, Piutang, dan Modal Kerja dengan baik karena rasio ini sangat berpengaruh pada laba perusahaan. Bagi peneliti selanjutnya diharapkan mempertimbangkan hal yang sama dengan periode berbeda atau dapat memasukkan variabel lain yang berhubungan dengan Profitabilitas untuk menyempurnakan penelitian ini.

\section{DAFTAR PUSTAKA}

Agustia Kadek, Wayan Suwendra dan Fridayana Yudiaatmaja. (2016). Pengaruh Perputaran Kas, Perputaran Piutang, dan Perputaran Persediaan terhadap Profitabilitas pada Perusahaan Manufaktur di Bursa Efek Indonesia Tahun 2014. Jurnal Jurusan Manajemen Universitas Pendidikan Ganesha Singaraja, Indonesia.

Ambarwati Sagita Novi, Gede Adi Yuniarta, dan Ni Kadek Sinarwati. (2015). Pengaruh Modal Kerja, Likuiditas, Aktivitas dan Ukuran Perusahaan terhadap Profitabilitas pada Perusahaan Manufaktur yang Terdaftar di Bursa Efek Indonesia Periode 20062010. Jurusan Akuntansi Program S1 Universitas Pendidikan Ganesha Singaraja, Indonesia.

Arinda Putri Nawalani dan Wiwik Lestari. (2015) Pengaruh modal kerja terhadap profitabilitas pada perusahaan food and beverages di Bursa Efek Indonesia. Journal of Business and Banking. Vol 5, No 1. DOI: http://dx.doi.org/10.14414/jbb.v5i1.472.

Arry Eksandy dan Vera Mustika Dewi. (2019). Pengaruh Perputaran Modal Kerja, Perputaran Piutang dan Perputaran Kas Terhadap Profitabilitas Perusahaan (Studi pada Perusahaan Konstruksi Sektor Infrastruktur di Bursa Efek. Jurnal Dinamika UMT 2 (2), 1-14. 
Budiansyah Oktary, Yancik Safitri dan Cherrya D.W. (2015). Pengaruh Perputaran Kas, Perputaran Piutang, dan Perputaran Persediaan terhadap Profitabilitas tahun 20122014. Jurnal Jurusan Manajemen, STIE 1MDP, Palembang.

Christiana, Sintje Nangoy, dan Ivonne S. Saerang. (2017). Pengaruh Perputaran Modal Kerja dan Profitabilitas terhadap Nilai Perusahaan pada Perusahaan Farmasi di Bursa Efek Indonesia. periode 2010-2013. Jurusan Manajemen, Fakultas Ekonomi dan Bisnis Universitas Sam Ratulangi Manado, Indonesia.

Deni Irman. (2014). Pengaruh Tingkat Perputaran Kas, Perputaran Piutang dan Perputaran Persediaan terhadap Profitabilitas pada Perusahaan Manufaktur yang terdaftar di Bursa Efek Indonesia Tahun 2009-2011. Jurnal Program Studi Akuntansi, Fakultas Ekonomi, Universitas Maritim Raja Ali Haji Umrah.

Dini Pratiwi. (2018). Pengaruh Perputaran Modal Kerja, Perputaran Piutang dan Perputaran Persediaan Terhadap Profitabilitas pada Perusahaan Industri Barang Konsumsi di Bursa Efek Indonesia. Jurnal Ilmu Manajemen 7 (1), 77-89.

Eka Ayu Rahayu. (2014). Pengaruh Perputaran Kas, Perputaran Piutang Dan Perputaran Persediaan Terhadap Profitabilitas Perusahaan Manufaktur. Jurnal Ilmu Manajemen (JIM) Vol 2, No 4.

Fahmi Irham. (2016). Pengantar Manajemen Keuangan Teori dan Soal Jawab. Bandung: Penerbit Alfabeta.

Ghozali Imam. (2013). Aplikasi Analisis Multivariente dengan Program SPSS Ed 7,

Semarang : Badan Penerbit Universitas Diponegoro

Handayani, Sri. (2016). Pengaruh Perputaran Modal Kerja, Perputaran Kas, Perputaran Piutang Terhadap Profitabilitas pada PT. Mayora Indah Tbk. Jurnal Analisis Manajemen 2 (1), 1-11.

Hery. (2015). Analisis Laporan Keuangan Pendekatan Rasio Keuangan. CAPS (Center of Academic Publishing Service). Kota. Yogyakarta.

Hery. (2015). Pengantar Akuntansi Comperhensive Edition. Jakarta:Gasindo

Indah Risky Purwatiningtias. (2019). Pengaruh Perputaran Modal Kerja, Perputaran

Kas, Perputaran Piutang dan Perputaran Persediaan Terhadap Profitabilitas

Perusahaan (Studi pada Perusahaan Manufaktur Sub Sektor). Universitas

Pancasakti Tegal.

Kasmir. (2014). Analisis Laporan Keuangan. Rajawali Pers Jakarta.

Kezia Vita Natalia, Kharis Raharjo, dan Agus Supriyanto. (2017). Pengaruh Perputaran

Modal Kerja, Perputaran Kas Perputaran Piutang dan Perputaran Persediaan

Terhadap Profitabilitas Perusahaan Manufaktur yang Terdaftar di BEI Tahun 2011 2015. Journal of Accounting 3 (3).

Matilda Amaral Canizio. (2017). Pengaruh Perputaran Kas, Perputaran Piutang, Perputaran Persediaan Terhadap Profitabilitas pada Supermarket di Timor Leste. EJurnal Ekonomi dan Bisnis Universitas Udayana 6 (10), 3527-3548.

Narufika Ayu Rika dan Khairunnisa Almadany. (2018). Pengaruh Perputaran Kas, Perputaran Piutang, Perputaran Persediaan terhadap Profitabilitas pada Perusahaan Semen yang terdaftar di Bursa Efek Indonesia periode 2015. Jurnal Program Studi Akuntansi Politeknik LP3I Medan.

Novi Sagita Ambarwati., Gede Adi Yuniarta., dan Ni Kadek Sinarwati. (2015). Pengaruh Modal Kerja, Likuiditas, Aktivitas Dan Ukuran Perusahaan Terhadap Profitabilitas Pada Perusahaan Manufaktur Yang Terdaftar Di Bursa Efek Indonesia. Jurnal Ilmiah 
Mahasiswa Akuntansi UNDIKSHA.Vol 3, No 1. DOI: http://dx.doi.org/10.23887/jimat.v3i1.4727.

Novita Panca Rini. (2015). Pengaruh Perputaran Modal Kerja, Perputaran Kas, Perputaran Piutang dan Perputaran Persediaan Terhadap Profitabilitas pada Industri Barang Konsumsi yang Terdaftar di Bursa Efek. Journal of Accounting 1 (1).

Nurri Lestari, Wayan Rai Suarthana, dan Asep Alipudin. (2017). Pengaruh Perputaran Kas, Perputaram Piutang Usaha, dan Perputaran Persediaan Terhadap Profitabilitas pada Perusahaan Sub Sektor Makanan dan Minuman yang Terdaftar di Bursa Efek. Jurnal Online Mahasiswa (JOM) Bidang Akuntansi 2 (2).

Nurul Pratiwi Utami. (2014). Pengaruh Perputaran Kas, Perputaran Piutang, Perputaran Persediaan Terhadap Profitabilitas Perusahaan Non Perbankan yang Terdaftar pada LQ-45 Periode 2008-2012. Universitas Widyatama.

Puspita Ayu Debby dan Ulil Hartono. (2018). Pengaruh Perputaran Modal Kerja, Ukuran Perusahaan, Leverage dan Likuiditas terhadap Profitabilitas Perusahaan Animal Feed di BEI Periode 2012-2015. Jurnal Ilmu Manajemen Jurusan Manajemen Fakultas Ekonomi Universitas Negeri Surabaya.

Rany Widhi Astuti. (2017). Pengaruh Perputaran Modal Kerja, Perputaran Kas, Perputaran Piutang, Perputaran Persediaan Terhadap Profitabilitas pada Perusahaan Manufaktur Sektor Industri Barang Konsumsi. Fakultas Ekonomi dan Bisnis Universitas Muhammadiyah Surakarta.

Ririn Arianti dan N. Rusnaeni. (2018). Pengaruh Perputaran Piutang, Perputaran Kas dan Perputaran Persediaan Terhadap Profitabilitas PT. Ultrajaya Milk Industry \& Trading Company, Tbk. Proseding Seminar Nasional Akuntansi 1 (1).

Rofi Anura Hutami. (2018). Pengaruh Perputaran Modal Kerja, Perputara Kas, Perputaran Piutang dan Perputaran Persediaan Terhadap Profitabilitas pada Perusahaan Tekstil dan Garmen yang Terdaftar di BEI. Universitas Muhammadiyah Surakarta.

Sarjito Surya, Ruly Ruliana, Dedi Rossidi Soetama. (2017). Akuntabilitas. Jurnal Ilmu Akuntansi 10 (2), 2461-1190.

Satriya, I Made Dian dan Lestari Putu Vivi. (2014). Pengaruh Perputaran Modal Kerja

Terhadap Profitabilitas Perusahaan. E-Jurnal Manajemen. Vol 3 No 7.

Situs Bursa Efek Indonesia : http://www.idx.co.id.

Sugiyono. (2017). Metode Penelitian Kuantitatif, Kualitatif dan R\&D. Bandung:Alfabeta. Suminar Tejo Mohamad. (2015). Pengaruh Perputaran Persediaan, Perputaran Piutang dan

Perputaran Kas terhadap Profitabilitas pada Perusahaan Sektor Industri Barang Konsumsi yang Terdaftar Di BEI Periode 2008-2013. Jurnal Program Studi Akuntansi, Fakultas Ekonomi, Universitas Pandanaran.

Tiong Piter. (2017). Pengaruh Perputaran Piutang terhadap Profitabilitas pada Perusahaan PT Mitra Phinastika Mustika Tbk. Jurnal Program Pasca Sarjana STIE AMKOP Makassar.

Widiasmoro Rio. (2017). Pengaruh Perputaran Kas, Perputaran Piutang, dan Perputaran Persediaan terhadap Profitabilitas ROA pada Perusahaan Manufaktur yang Terdaftar di Bursa Efek Indonesia Tahun 2011-2014. Jurnal Mahasiswa Prodi Akuntansi Fakultas Ekonomi UNSA. 